3. Timmerman R, Paulus R, Galvin J, Michalski J, Straube W, Bradley J, et al. Stereotactic body radiation therapy for inoperable early stage lung cancer. JAMA 2010;303:1070-6

4. Timmerman RD, Paulus R, Pass HI, Gore EM, Edelman MJ, Galvin J, et al Stereotactic body radiation therapy for operable early-stage lung cancer: findings from the NRG Oncology RTOG 0618 trial. JAMA Oncol. 2018;4 1263-6.

5. Ginsberg RJ, Rubinstein LV, Lung Cancer Study Group. Randomized trial of lobectomy versus limited resection for T1N0 non-small cell lung cancer. Ann Thorac Surg. 1995;60:615-22.
See Article page 1389.

\section{Commentary: Second ipsilateral metachronous lung cancer: What to do?}

\author{
Antonio D'Andrilli, MD, and Erino A. Rendina, MD
}

The article by Hattori and colleagues ${ }^{1}$ deals with an interesting and still not sufficiently explored issue in thoracic surgery: the role of repeated anatomic resection for radical treatment of second metachronous ipsilateral non-small cell lung cancer (NSCLC). Although the incidence of a second primary lung cancer occurring ipsilaterally after curative resection is limited to $1 \%$ to $2 \%$ of patients, this topic carries increasing clinical implications, mainly due to the expanding indications for segmentectomy to treat stage IA NSCLC and to the progressively more frequent early detection of second NSCLC because of improved diagnostic technology and oncologic surveillance..$^{2-4}$

In this clinical scenario, the present article provides several meaningful scientific messages. The first is that, when feasible, a nonanatomic re-resection can be an adequate therapeutic choice because overall survival and recurrence-free survival results are comparable to those after anatomic reresection, but postoperative morbidity is lower. This is particularly true for less aggressive tumors such as peripheral adenocarcinoma with ground-glass opacity component.

From the Department of Thoracic Surgery, Sapienza University, Sant'Andrea Hospital, Rome, Italy.

Disclosures: Dr D'Andrilli received a lecture fee from Baxter. Dr Rendina has reported no conflicts of interest.

The Journal policy requires editors and reviewers to disclose conflicts of interest and to decline handling or reviewing manuscripts for which they may have a conflict of interest. The editors and reviewers of this article have no conflicts of interest.

Received for publication July 21, 2020; revisions received July 21, 2020; accepted for publication July 22, 2020; available ahead of print July 24, 2020.

Address for reprints: Antonio D'Andrilli, MD, Department of Thoracic Surgery, Sant'Andrea Hospital, Sapienza University of Rome, Via di Grottarossa 1035, 00189 Rome, Italy (E-mail: adandrilli@hotmail.com).

J Thorac Cardiovasc Surg 2021;162:1400-1

0022-5223/\$36.00

Copyright (c) 2020 by The American Association for Thoracic Surgery

http://dx.doi.org/10.1016/j.jtcvs.2020.07.070
Check for updates

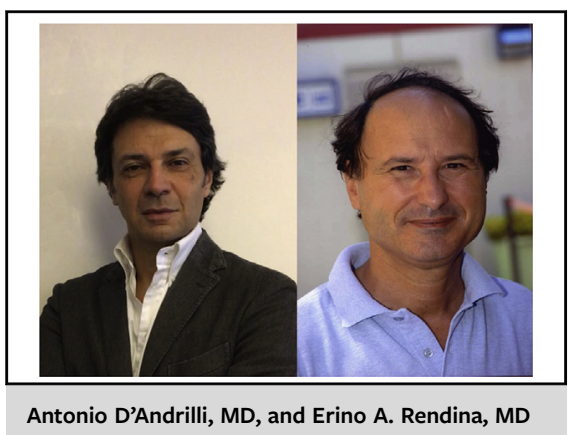

CENTRAL MESSAGE

Repeated anatomic

parenchymal-sparing resection

for the treatment of metachro-

nous ipsilateral NSCLC should be

preferred to CP when nonana-

tomic resection is not feasible.

The second important message is that when a repeated nonanatomic resection is not feasible (mainly due to tumor size and location), attempt to avoid completion pneumonectomy $(\mathrm{CP})$ performing anatomic parenchymal-sparing resections is justified, because these procedures show similar surgical outcomes (in terms of morbidity, mortality, and long-term survival) compared with $\mathrm{CP}$ and allow beneficial preservation of lung parenchyma and lower rate of life-threatening complications. This could indicate a novel promising strategy when approaching a second metachronous ipsilateral lung cancer. CP remains a valid option if no lesser resection is technically possible because of the large size and central location of the tumor.

A further evidence pointed out by this article is that repeated anatomic resections are demanding procedures requiring adequate surgical skill and judgment. The presence of dense adhesions and hilar fibrosis is almost the rule, with consequent potential need for challenging technical tasks including reconstructive procedures. 
Main limitations of the present article include selection bias, which are unavoidable when considering a retrospective study like this, and the limited statistical sample, although few similar series have been reported in the literature so far, with most of published data referring to second contralateral tumors. ${ }^{5}$

Comparison with patients undergoing stereotactic body radiation therapy is often considered as a crucial point to assess the role of reoperations for ipsilateral metachronous lung cancer. However, caution should be used when comparing results of stereotactic body radiation therapy, especially because series of patients undergoing irradiation have not had pathological staging and have variable inclusion criteria, sometimes without a conclusive histologic diagnosis. ${ }^{4,6}$

Anatomic parenchymal-sparing re-resection seems a promising route in this clinical setting. However, the benefit of sparing lung parenchyma with respect to CP may appear questionable in some particular cases, as that reported by Hattori and colleagues ${ }^{1}$ of a right lower lobectomy after previous ipsilateral upper lobectomy, leaving only the residual middle lobe. Therefore, further specific evaluation for each type of anatomic operation will be necessary to provide more precise and thorough indications for such interventions.

\section{References}

1. Hattori A, Matsunaga T, Watanabe Y, Fukui M, Takamochi K, Oh S, et al. Repeated anatomical pulmonary resection for metacronous ipsilateral second non-small cell lung cancer. J Thorac Cardiovasc Surg. 2021;162:1389-98.e2.

2. D'Andrilli A, Rendina EA. Should segmentectomy rather than lobectomy be the operation of choice for early-stage non-small cell lung cancer? Yes. Chest. 2018;153:590-2.

3. D'Andrilli A, Rendina EA. Rebuttals from Drs D'Andrilli and Rendina. Chest 2018;153:595-6.

4. Spratt DE, Wu AJ, Adeseye V, Din SU, Shaikh F, Woo KM, et al. Recurrence patterns and second primary lung cancers after stereotactic body radiation therapy for early -stage non-small-cell lung cancer. Implications for surveillance. Clin Lung Cancer. 2016;17:177-83.e2.

5. Hamaji M, Ali SO, Burt BM. A meta-analysis of resected metacronous second non-small cell lung cancer. Ann Thorac Surg. 2015;99:1470-8.

6. Rosen JE, Salazar MC, Wang Z, Yu JB, Decker RH, Kim AW, et al. Lobectomy versus stereotactic body radiotherapy in healthy patients with stage I lung cancer. J Thorac Cardiovasc Surg. 2016;152:44-54.e9.

\section{See Article page 1389.}

\section{Commentary: Not only safety but also efficacy is required in repeat pulmonary resection for second non-small cell lung cancer}

\section{Ke-Neng Chen, MD, PhD}

In this issue of the Journal, Hattori and colleagues ${ }^{1}$ reviewed the records of 104 patients who underwent surgical resection for ipsilateral metachronous second non-small cell lung cancer. The authors found that $74 \%$ of the patients were diagnosed as second primary cases, for which the 3year overall survival (OS) was $80.1 \%$. The survival data were favorable in terms of oncologic effect. However, we need stronger data to support the concept of repeat resection

From Thoracic Surgery Peking University Cancer Hospital, Beijing, China.

Disclosures: The author reported no conflicts of interest.

The Journal policy requires editors and reviewers to disclose conflicts of interest and to decline handling or reviewing manuscripts for which they may have a conflict of interest. The editors and reviewers of this article have no conflicts of interest.

Received for publication Aug 4, 2020; revisions received Aug 4, 2020; accepted for publication Aug 5, 2020; available ahead of print July 15, 2020.

Address for reprints: Ke-Neng Chen, MD, PhD, No. 52, Fucheng Rd, Haidian

District, Beijing, China 100142 (E-mail: chenkeneng@bjmu.edu.cn).

J Thorac Cardiovasc Surg 2021;162:1401-3

$0022-5223 / \$ 36.00$

Copyright (c) 2020 by The American Association for Thoracic Surgery

http://dx.doi.org/10.1016/j.jtcvs.2020.08.009

\section{Check for updates}

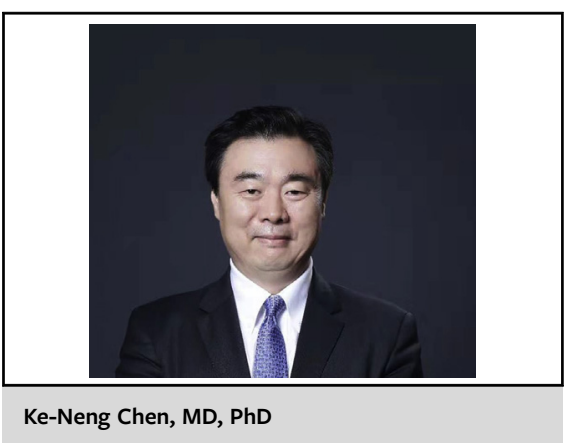

CENTRAL MESSAGE

We need stronger data to sup-

port the concept of repeat

resection for second primary

lung cancer. As well, other phy-

sicians need to understand the

concept for it to be widely

followed.

for second primary lung cancer after pulmonary resection. As well, physicians from many disciplines need to understand the concept for it to be widely followed by in addition to thoracic surgery. Two aspects of this topic require attention, discussed to follow. 